\title{
Impact of salt reduction on biogenic amines, fatty acids, microbiota, texture and sensory profile in traditional blood dry-cured sausages
}

\author{
Marta Laranjo a, Ana Gomes ${ }^{\mathrm{b}}$, Ana Cristina Agulheiro-Santos ${ }^{\mathrm{a}, \mathrm{b}}$, Maria Eduarda Potes ${ }^{\mathrm{a}, \mathrm{c}}$, \\ Maria João Cabrita ${ }^{\mathrm{a}, \mathrm{b}}$, Raquel Garcia a ${ }^{\mathrm{a}}$, João Miguel Rocha ${ }^{\mathrm{a}, 1}$, Luísa Cristina Roseiro ${ }^{\mathrm{d}}$, Maria José Fernandes ${ }^{\mathrm{e}}$, \\ Maria João Fraqueza ${ }^{\mathrm{e}}$, Miguel Elias ${ }^{\mathrm{a}, \mathrm{b}, *}$ \\ a Instituto de Ciências Agrárias e Ambientais Mediterrânicas (ICAAM), Instituto de Investigação e Formação Avançada (IIFA), Universidade de Évora, Pólo da Mitra, \\ Ap. 94, 7002-554 Évora, Portugal \\ ${ }^{\mathrm{b}}$ Departamento de Fitotecnia, Escola de Ciências e Tecnologia, Universidade de Évora, Pólo da Mitra, Ap. 94, 7002-554 Évora, Portugal \\ ${ }^{\mathrm{c}}$ Departamento de Medicina Veterinária, Escola de Ciências e Tecnologia, Universidade de Évora, Pólo da Mitra, Ap. 94, 7002-554 Évora, Portugal \\ ${ }^{\mathrm{d}}$ Instituto Nacional de Investigação Agrária e Veterinária, I.P., Campus do IAPMEI (Edifício S), Estrada do Paço do Lumiar, 22, 1649-038 Lisboa, Portugal \\ e CIISA, Faculty of Veterinary Medicine, University of Lisbon, Avenida da Universidade Técnica, Pólo Universitário do Alto da Ajuda, 1300-477 Lisbon, Portugal
}

\section{A R T I C L E I N F O}

\section{Article history:}

Received 4 April 2016

Received in revised form 6 September 2016

Accepted 8 September 2016

Available online 8 September 2016

\section{Keywords:}

Dry-cured sausages

Blood

Biogenic amines

Fatty acids

Microbiology

Food safety

Texture profile analysis

Sensory evaluation

\begin{abstract}
A B S T R A C T
Meat industry needs to reduce salt in their products due to health issues. The present study evaluated the effect of salt reduction from $6 \%$ to $3 \%$ in two Portuguese traditional blood dry-cured sausages. Physicochemical and microbiological parameters, biogenic amines, fatty acids and texture profiles and sensory panel evaluations were considered. Differences due to salt reduction were perceptible in a faint decline of water activity, which slightly favoured microbial growth. Total biogenic amines content ranged from 88.86 to $796.68 \mathrm{mg} \mathrm{kg}^{-1}$ fresh matter, with higher amounts, particularly of cadaverine, histamine and tyramine, in low-salt products. Still, histamine and other vasoactive amines remained at low levels, thus not affecting consumers' health. Regarding fatty acids, no significant differences were observed due to salt. However, texture profile analysis revealed lower resilience and cohesiveness in low-salt products, although no textural changes were observed by the sensory panel. Nevertheless, low-salt sausages were clearly preferred by panellists.
\end{abstract}

(c) 2016 Elsevier Ltd. All rights reserved.

\section{Introduction}

Health issues such as cardiovascular disease are often due to dietary habits. From an epidemiological standpoint, cardiovascular diseases have a substantial incidence, affecting a significant part of the world population, which according to the World Health Organisation (WHO) is one of the main causes of death (2015).

Among other factors, an excessive salt consumption is pointed out as a major risk factor, due to its direct relation with blood pressure disturbances (Ruusunen \& Puolanne, 2005), that can lead to hypertension issues. Although the recommended salt intake ranges from 3.7 to $5.8 \mathrm{~g}$ per day (Bibbins-Domingo et al., 2010), it is esti-

\footnotetext{
* Corresponding author at: Departamento de Fitotecnia, Escola de Ciências e Tecnologia, Universidade de Évora, Pólo da Mitra, Ap. 94, 7002-554 Évora, Portugal.

E-mail address: elias@uevora.pt (M. Elias).

${ }^{1}$ New addresses: Centro de Engenharia Biológica, Universidade do Minho, Campus de Gualtar, 4710-057 Braga, Portugal. Departamento de Engenharia Química, Faculdade de Engenharia da Universidade do Porto, Rua Dr. Roberto Frias, 4200-465 Porto, Portugal.
}

mated that this might be much higher, from 8 to $10 \mathrm{~g}$ (Desmond, 2006). For this reason, WHO recommendations are to reduce salt consumption and its negative impact on consumers' health (http://ec.europa.eu/health/nutrition_physical_activity/high_level_ group/nutrition_salt_en.htm). Recent studies have suggested that reducing $3 \mathrm{~g}$ per day in salt intake could represent a decrease in the number of annual deaths between 44,000 and 92,000 , as well as a saving about 10-24 billion dollars in health care per year, in the U. S. alone (Bibbins-Domingo et al., 2010). Whether by adding less salt during food gastronomic preparation or avoiding processed food containing high salt levels, consumers' concerns have resulted on a generalised trend to lower salt consumption (Guardia, Guerrero, Gelabert, Gou, \& Arnau, 2006).

In some countries, meat and meat products can account for over $20 \%$ of the salt dietary intake (Desmond, 2006; Guardia et al., 2006). Its effects in reducing water activity and antimicrobial activity, increasing water retention capacity (thus enabling protein solubilisation) and decreasing the activity of some enzymes, are the main reasons, which make salt essential for the meat industry 
(Desmond, 2006). From a sensory perspective, salt enhances the products' texture, as well as the characteristic salty taste associated to meat products.

For this reason, production of low-salt content dry-cured sausages must assure not only safe and stable products, but also that consumers' acceptability is not affected. In previous studies, lower salty taste and less intensive colour were perceived when less salt was used (Corral, Salvador, \& Flores, 2013; Zanardi, Ghidini, Conter, \& Ianieri, 2010). On the other hand, due to its oxidative properties, different salt contents can also lead to changes in lipid oxidation profile. Another problem related to salt reduction concerns the increased microbial decarboxylase activity that can lead to higher levels of biogenic amines (Roseiro, Santos, Sol, Silva, \& Fernandes, 2006; Suzzi \& Gardini, 2003). There are two main reasons why the presence of biogenic amines is related to meat and meat products' quality and safety. On one hand, biogenic amines (such as tryptamine, $\beta$-phenylethylamine, putrescine, cadaverine, histamine and tyramine) arise as a consequence of microbial growth. For this reason they are often used as good chemical indicators of products' hygienic quality (Stadnik \& Dolatowski, 2010). On the other hand, the biological activity of biogenic amines (mainly histamine, tyramine and tryptamine) has also been related to the occurrence of adverse reactions in the cardiovascular and neurological systems, making their ingestion an important health concern (Suzzi \& Gardini, 2003).

In Mediterranean countries, including Portugal, Spain and Italy, traditional dry-cured sausages are widely appreciated, frequently still being manufactured in small processing units, according to traditional practices specific for each geographic area (Elias \& Carrascosa, 2010; Moretti et al., 2004; Olivares, Navarro, Salvador, \& Flores, 2010). In Portugal, Alentejo is one of the most important regions for dry-cured sausages, where products like "Chouriço Preto" and "Paio Preto" stand out for their unique characteristics, which result from the use of Alentejano pig breed meat, the addition of blood (an important sensitive ingredient) and the manufacture know-how.

A previous study, using a different kind of sausages, has already highlighted that salt content may be significantly reduced without compromising food safety nor depreciating quality (Laranjo et al., 2016). Therefore, the present work intended to evaluate the effect of lower salt contents in these sausages regarding microbial, sensory and texture characteristics, as well as on fatty acids and biogenic amines profile throughout the ripening process.

\section{Materials and methods}

\subsection{Sausage technology and sampling procedures}

Three independent batches (30 kg of meat batter each) of "Chouriço Preto" (CP) and "Paio Preto" (PP) were produced in a local factory using commercial hybrid Iberian $\mathrm{x}$ Duroc pig breed meat.

Meat was initially cut into pieces measuring about $25 \mathrm{~mm}$ and then mechanically minced and mixed with salt, red pepper (Capsicum annuum L.) paste $(2.5 \% \mathrm{w} / \mathrm{w})$, water reconstituted $(1: 2$ $(\mathrm{w} / \mathrm{v})$ ) dried blood powder $(4 \% \mathrm{v} / \mathrm{w})$, garlic (Allium sativum L.) paste $(1 \% \mathrm{w} / \mathrm{w})$, disodium diphosphate $(0.03 \% \mathrm{w} / \mathrm{w})$, pentasodium triphosphate $(0.03 \% \mathrm{w} / \mathrm{w})$, nitrate $(0.003 \% \mathrm{w} / \mathrm{w})$ and nitrite $(0.003 \% \mathrm{w} / \mathrm{w})$. Nitrates and nitrites have been added in the form of the commercial additive NITROS 5/5 (Formulab, Portugal). Since red pepper and garlic pastes both have in its original composition $17 \%$ salt, salt was added to the mixture, so that final concentration in end-product was 3 and $6 \%$.

The meat mixture was let to rest under refrigeration at $5{ }^{\circ} \mathrm{C}$ and $90 \%$ relative humidity for a period of $48 \mathrm{~h}$, after which it was divided in two sub-batters (of approximately $15 \mathrm{~kg}$ each) and stuffed in natural casings obtained from pig intestine. Two different diameters were used: $36-38 \mathrm{~mm}$ from small intestine for $\mathrm{CP}$ (tied in a horseshoe shape) and $50-55 \mathrm{~mm}$ from large intestine (rectum) for PP.

After stuffing, sausages were kept in a smoking room with smoke generated from oak wood (Quercus ilex L.) during $48 \mathrm{~h}$, with temperatures ranging from 18 to $24^{\circ} \mathrm{C}$ and $30-60 \%$ relative humidity. After this smoking stage, sausages were dried under controlled conditions in cure chambers at $9{ }^{\circ} \mathrm{C}$ and $80-85 \%$ relative humidity. On average, the drying stage took about 14 or 30 days for $\mathrm{CP}$ and $\mathrm{PP}$, respectively, until 35\% weight losses were reached.

Three samples were collected at three different ripening stages: after stuffing, at 20\% weight loss and end-product (35\% weight loss). All samples were analysed for $\mathrm{pH}$, water activity $\left(\mathrm{a}_{\mathrm{w}}\right)$, microbiological parameters and biogenic amines content. End-products were also analysed for their fatty acids, texture profile and sensory attributes.

\subsection{Physicochemical analyses}

For $\mathrm{pH}$ assessment, sausages casings were removed and values measured with a Crison 507 (Barcelona, Spain) pH-meter following the procedures described in ISO 2917 (1999). Water activity was determined with a hygrometer (Hygroskop Rotronic DT, Zurich, Switzerland) equipped with a WA- 40 probe at $25^{\circ} \mathrm{C}$. Salt content of end-products was confirmed through determination of chlorides according to the Volhard method as described in ISO 1841-1 (1996).

\subsection{Microbiological analyses}

Microbiological analyses were carried out according the analytical protocols described by Laranjo et al. (2015). Briefly, decimal dilution series were prepared in buffered peptone water (Scharlau, Spain), plated and incubated as follows: mesophiles in Tryptone Glucose Extract (TGE) Agar (Scharlau, Spain) at $30^{\circ} \mathrm{C}$ for $48 \mathrm{~h}$; lactic acid bacteria (LAB) in de Man, Rogosa and Sharpe (MRS) Agar (Scharlau, Spain) at $30^{\circ} \mathrm{C}$ for $48 \mathrm{~h}$ under anaerobic conditions in an AnaeroJar (Oxoid, UK) using an AnaeroGen sachet (Oxoid, UK); enterobacteria in Violet Red Bile Glucose (VRBG) Agar (Biokar, France) at $30^{\circ} \mathrm{C}$ for $48 \mathrm{~h}$; enterococci in Slanetz and Bartley Agar (Biokar, France) at $37^{\circ} \mathrm{C}$ for $48 \mathrm{~h}$; staphylococci in Mannitol Salt Agar (MSA) (Biokar, France) at $37{ }^{\circ} \mathrm{C}$ for $48 \mathrm{~h}$; yeasts and moulds in Rose Bengal Chloramphenicol Agar (Scharlau, Spain) at $25^{\circ} \mathrm{C}$ for 5 days.

Enumeration of Campylobacter spp. was performed according to the ISO 10272-2 (2006). Escherichia coli counts followed the procedures described in ISO 16649-2 (2012a). Listeria monocytogenes enumeration was performed according to standard procedures described in ISO 11290-2 (2014). Detection of Salmonella spp. was performed according to the ISO 6579 (2002).

All microbiological analyses were performed in triplicate and the results expressed in $\log \mathrm{cfu} \mathrm{g}^{-1}$, while for Salmonella spp. the presence/absence was denoted by the growth of typical colonies with isolation and biochemical identification.

\subsection{Biogenic amine analysis}

Biogenic amines quantification was performed according to the experimental protocol described by Roseiro et al. (2006).

Four grams of sample previously homogenized were extracted with $40 \mathrm{~mL}$ perchloric acid aqueous solution $(0.4 \mathrm{M})$. The extract was then centrifuged for $10 \mathrm{~min}$ at $800 \mathrm{~g}$ and the supernatant was filtered. Resulting pellet was extracted once more and supernatants were combined. Internal standard (1,7-diaminoheptane) 
was added and final volume adjusted to $50 \mathrm{~mL}$. All extractions were performed in duplicate.

Biogenic amines were then derivatised with dansyl chloride in alkaline medium. After the excess of dansyl chloride has been removed, and the extract diluted in acetonitrile, samples were filtered through an Acrodisc membrane $25 \mathrm{~mm}$ GHP, GF $0.45 \mu \mathrm{m}$ (Gelman Sciences, Inc.) and an aliquot $(20 \mu \mathrm{L})$ of this extract was injected into an HPLC system in duplicate. Chromatographic separation was carried out in a Spherisorb $5 \mu \mathrm{m}$ ODS2 column with $4.0 \times 125 \mathrm{~mm}$ (Waters, Germany), coupled to an Alliance Separation Module 2695 (Waters, Milford, MA), using a gradient elution program combining aqueous ammonium acetate solution and acetonitrile (Panreac, Barcelona, Spain) (Roseiro et al., 2006). Biogenic amines detection was achieved at $254 \mathrm{~nm}$ using a Dual $\lambda \mathrm{UV} / \mathrm{Vis}$ Detector 2487 (Waters, Milford, MA). Biogenic amines final results were express in $\mathrm{mg} \mathrm{kg}^{-1}$ in a fresh matter basis.

\subsection{Fatty acids profile}

After processing, samples were mechanically homogenised, lyophilised and stored at $4{ }^{\circ} \mathrm{C}$ in glass flasks until further analysis. Procedures regarding fatty acid profile analysis were based in method previously published by Laranjo et al. (2015). Briefly, fatty acids extraction was carried out in triplicate by accelerated solvent extraction (ASE), using a Dionex 100 system equipped with a $34 \mathrm{~mL}$ stainless steel cell (fitted with two cellulose filters) followed by their derivatization in order to give fatty acid methyl esters (FAMEs), which were further determined using a GC system (Hewlett Packard 6890 Series) equipped with split-splitless injector, an auto-sampler, a flame-ionisation detector (FID), an Omegawax 320 fused silica capillary column $(30 \mathrm{~m} \times 0.32 \mathrm{~mm}$ i.d., $0.25 \mu \mathrm{m}$ film thickness, Supelco, Bellefonte, PA, USA) and HPChem software (2002). During chromatographic analysis, oven temperature was raised from $140{ }^{\circ} \mathrm{C}$ to $240{ }^{\circ} \mathrm{C}$ at $4^{\circ} \mathrm{C} \mathrm{min}{ }^{-1}$ while temperatures of injector and detector were set to 250 and $270{ }^{\circ} \mathrm{C}$, respectively. Helium was used as carrier gas and was flowing through the system at a $1.2 \mathrm{~mL} \mathrm{~min}^{-1}$ rate. Identification of fatty acid methyl esters (FAMEs) was based on comparison of retention times of known composition standards mixtures (37-component FAME mix, Supelco). For each sample, the relative fatty acid methyl esters (FAMEs) composition was quantified and data presented as percentage weight for FAMEs composition.

\subsection{Texture profile analysis}

Texture profile analysis (TPA) tests were performed at room temperature $\left(20^{\circ} \mathrm{C} \pm 1^{\circ} \mathrm{C}\right)$ according the analytical protocol from Laranjo et al. (2015) . A cylindrical flat-ended plunger (with a diameter of $1.13 \mathrm{~cm}$ and an area of $1 \mathrm{~cm}^{2}$ ) coupled to a Stable Micro System TA-Hdi (Stable Micro Systems, Godalming, England) was used in double compression cycle tests of five slices with $1 \mathrm{~cm}$ thick and $4-5 \mathrm{~cm}$ (for PP) and $2-2.5 \mathrm{~cm}$ (for $\mathrm{CP}$ ) diameter from three different sausages. The hardness, adhesiveness, springiness, cohesiveness, resilience and chewiness were assessed from force/ time curves obtained for double $50 \%$ compressions at $1 \mathrm{~mm} / \mathrm{s}$ speed, separated for $5 \mathrm{~s}$ intervals each.

\subsection{Sensory evaluation}

Product sensory evaluation took place in a special room according to ISO 8589 (2012b). For each session, sausages were prepared with an advance of $30 \mathrm{~min}$ and cut into $3 \mathrm{~mm}$ thick slices. Three samples were randomly disposed in white small dishes codified with a three-digit number. The group of 10 trained panellists including 5 men and 5 women (within 40-60 years old) selected following ISO 8586-1 (1993) were asked to rate the product according to the following attributes: colour intensity, offcolours, marbled, aroma intensity, off-aromas, hardness, fibrousness, succulence, flavour intensity, off-flavours, salt perception and overall appreciation. For each attribute a scale ranging from 0 to 100 was used, corresponding to "no perception" or "maximum perception", respectively. Salt perception was the exception, where $50 \%$ would correspond to the optimum value. In this case, values below $50 \%$ indicate low salt contents while higher rates would indicate high salt contents. Each panellist tasted three sausages per session. Neutral water and crackers were provided, so that judges could rinse their mouths between evaluations.

\subsection{Statistical analysis}

Results were analysed according to factorial ANOVAs and Principal Component Analysis (PCA) using Statistica ${ }^{\mathrm{TM}}$ v.8.0, software from Statsoft (StatSoft Inc, 1984-2007). Differences between groups were identified based on Tukey's Honest Significant Difference (Tukey's HSD) test $(P<0.05)$. Elimination of outliers in biogenic amines data was carried out according to the Grubbs test $(\alpha=0.05)$.

Analyses of variance (ANOVA) for the factors salt content, calibre (product type) and weight losses were performed. No differences were found between batches and therefore all replicates were analysed together without taking the factor batch into account.

\section{Results and discussion}

\subsection{Physicochemical analyses}

The results regarding physicochemical analyses are shown in Fig. 1.

$\mathrm{NaCl}$ contents of low-salt (3\%) products are significantly different than those of regular-salt (6\%) products, as expected (data not shown).

Considering their influence in dry-cured sausages' safety and quality, $\mathrm{pH}$ and $\mathrm{a}_{\mathrm{w}}$ were evaluated throughout the manufacturing process. For both physicochemical parameters, salt content had a significant effect $(P<0.001)$ (Fig. 1 (A) and Fig. 1 (B)).

Meat batters showed pH values of 4.64 and 4.96 for formulations containing 3 and 6\% salt, respectively (Fig. 1 (A)). Acidity decreased throughout ripening, regardless of salt content, with special emphasis on CP samples (Fig. 1 (A)). Nevertheless, lowsalt end-products' $\mathrm{pH}$ values remained low for PP (4.79) and CP (4.91), while regular-salt sausages reached significantly higher $\mathrm{pH}$ values (5.44 in $\mathrm{CP}$ and 5.17 in $\mathrm{PP})(P<0.05)$ (Fig. $1(\mathrm{~A})$ ).

Meat batters were first subjected to a two-day resting period, enabling $\mathrm{LAB}$ to grow thus releasing lactic acid and leading to a $\mathrm{pH}$ decrease. The presence of higher amounts of salt also allowed a more intense soluble protein extraction from muscle cells and increased the buffer effect. Thus, higher salt concentrations favour higher $\mathrm{pH}$ values, which has also been observed in previous works (Laranjo et al., 2015). pH of our end-products is characteristic of slowly cured meat products, despite the observed $\mathrm{pH}$ increase throughout the ripening process due to proteolytic activity of microorganisms. pH is significantly influenced by product calibre, with PP (larger calibre) samples showing more acidic values (Fig. 1 (A)). Bover-Cid, Schoppen, Izquierdo-Pulido, and VidalCarou (1999) also found a negative correlation between $\mathrm{pH}$ and product calibre. According to these authors, lower $\mathrm{pH}$ values were found in the sausages' external layer, when compared to the inside. Since LAB are microaerophilic microorganisms and thus able to grow in environments with lower oxygen amounts, such results would be related with their better development on the outside 
(A)

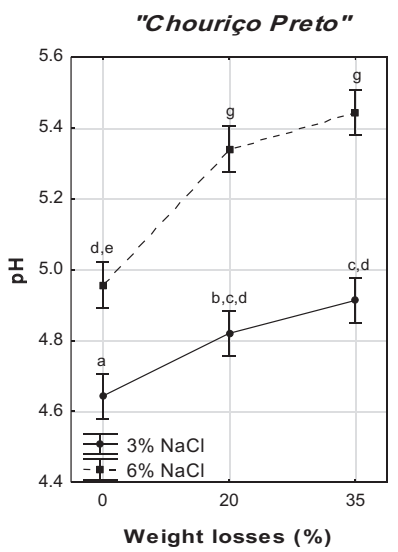

"Paio Preto"

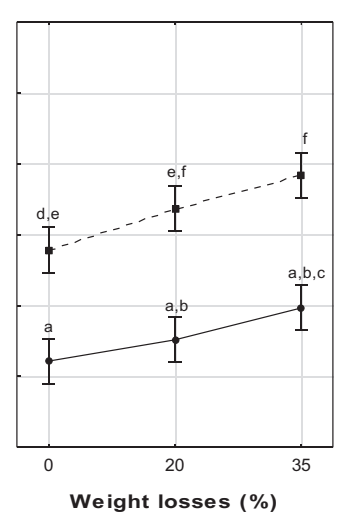

(B)

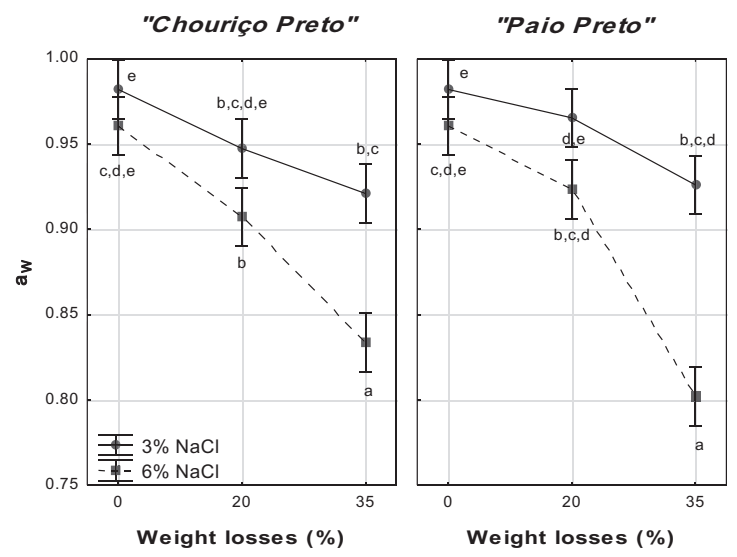

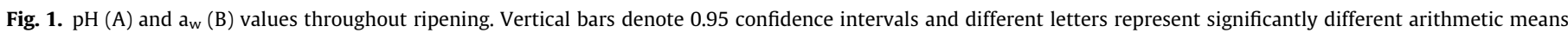
(Tukey's HSD test).

layer, thus contributing to a $\mathrm{pH}$ reduction. In fact, we detected a slightly higher development of LAB in $6 \% \mathrm{PP}$, which could explain the lower $\mathrm{pH}$ of these samples $(P>0.05)$.

No significant differences were observed for $a_{w}$ between the low- $\left(\mathrm{a}_{\mathrm{W}}=0.98\right)$ and regular-salt $\left(\mathrm{a}_{\mathrm{W}}=0.96\right)$ meat batters $(P>0.05)$ (Fig. 1 (B)). Nevertheless, significant differences were observed in end-products (Fig. 1 (B)).

Salt reduction decreases the ability of proteins to retain water and thus, even though a reduction of $\mathrm{a}_{\mathrm{w}}$ was observed throughout curing, it was still above 0.90 , providing favourable conditions for microbiota development.

\subsection{Microbiological analyses}

Results from microbiological analyses by microbial group are shown in Table 1.

Enterobacteria counts were significantly different between the two calibres $(P<0.05)$. Generally, more enterobacteria were found in CP samples (Table 1$)$.

Mesophiles $(P<0.001)$, staphylococci $(P<0.001)$ and yeasts $(P<0.01)$ were significantly affected by salt content. Mesophiles' counts were generally higher in low-salt PP samples (Table 1). On the contrary, more staphylococci and yeasts were found in regular-salt products.

Considering weight losses, there are significant differences for mesophiles $(P<0.001)$, LAB $(P<0.05)$ and enterobacteria $(P<0.001)$. Mesophiles generally decreased between $0 \%$ and $20 \%$ and increased again between $20 \%$ and $35 \%$ weight losses. An identical behaviour was observed for LAB, which may suggest that the evolution in mesophiles is due mainly to LAB. Enterobacteria values were reduced throughout curing, with significantly lower values in end-products (35\% weight losses) when compared with meat batters. In our study, the highest enterobacteria counts were found in meat batters ( 6.80 and $4.80 \log \mathrm{cfu} \mathrm{g}^{-1}$, in low-salt and regular-salt formulations, respectively). Afterwards, enterobacteria consistently decreased for both formulations, concomitantly with LAB becoming dominant and the decrease in $\mathrm{a}_{\mathrm{w}}$, as previously reported (Elias \& Carrascosa, 2010). In fact, enterobacteria were absent in end-product $6 \%$ salt PP, which agrees with findings for products with identical ripening time and salt content (Roseiro et al., 2006). However, other authors had reported generally constant enterobacteria values throughout curing (Ambrosiadis, Soultos, Abrahim, \& Bloukas, 2004).

An interaction was observed between product calibre and weight losses for mesophiles $(P<0.01)$ : low-salt CP counts decreased throughout curing with significantly different values between meat batters and end-products, while in all other products mesophiles decreased between $0 \%$ and 20\% and increased again from $20 \%$ to $35 \%$ weight losses.

Interactions between salt content and weight losses were observed for mesophiles $(P<0.05)$, enterobacteria $(P<0.05)$, staphylococci $(P<0.001)$ and yeasts $(P<0.01)$. Staphylococci and yeasts showed higher values in $6 \%$ end-products when compared to the respective meat batters.

The triple interaction detected for mesophiles suggests that there is no standard pattern for the growth of mesophiles considering product calibre, salt content and weight losses.

The food pathogens Campylobacter spp., E. coli, L. monocytogenes and Salmonella spp. were not detected.

The addition of fresh blood, traditionally used for the manufacturing of dry-cured sausages, may compromise safety, due to its reduced shelf-life (Parés, Saguer, \& Carretero, 2011). However, the present results indicate that dried blood powder might be a safe and easy alternative to fresh blood.

\subsection{Biogenic amines}

Table 2 shows the contents of individual biogenic amines, as well as total and vasoactive amines (Eerola, Sagues, \& Hirvi, 1998).

All individual biogenic amines showed significantly different contents between the two calibres.

Salt reduction had a significant effect on most individual biogenic amines, with the exception of tryptamine and $\beta$ phenylethylamine, as well as in total and vasoactive amines groups $(P<0.001)$. The main differences found between regular- and lowsalt sausages were related to a generally higher content in low-salt sausages.

Differences concerning the biogenic amines profile were also observed depending on salt content. Generally, cadaverine alone corresponded to about $40 \%$ of the total biogenic amines content detected in low-salt products, followed by putrescine and tyramine, which amounted for nearly $20 \%$ each. Instead, in regularsalt dry-cured sausages, biogenic amines appeared in the following order: putrescine $>$ tryptamine $>$ tyramine (corresponding to about 40, 20 and 15\%, respectively).

The total content in biogenic amines ranged from 345.40 up to $796.68 \mathrm{mg} \mathrm{kg}^{-1}$ in low-salt sausages, and from 88.86 up to $332.13 \mathrm{mg} \mathrm{kg}^{-1}$ in regular-salt sausages (Table 2).

The content in vasoactive amines (histamine, $\beta$ phenylethylamine, tryptamine and tyramine) should be kept below 
Table 1

Factorial ANOVA for microbiological parameters regarding product calibre and salt content throughout ripening (\% weight losses).

\begin{tabular}{|c|c|c|c|c|c|c|c|c|c|c|c|c|c|c|c|c|c|c|c|}
\hline \multirow{3}{*}{$\begin{array}{l}\text { Sausage calibre } \\
\text { Salt content } \\
\text { Weight losses (\%) }\end{array}$} & \multicolumn{6}{|l|}{ "Chouriço Preto" } & \multicolumn{6}{|l|}{ "Paio Preto" } & \multicolumn{7}{|c|}{ Significance } \\
\hline & \multicolumn{3}{|l|}{$3 \% \mathrm{NaCl}$} & \multicolumn{3}{|l|}{$6 \% \mathrm{NaCl}$} & \multicolumn{3}{|l|}{$3 \% \mathrm{NaCl}$} & \multicolumn{3}{|l|}{$6 \% \mathrm{NaCl}$} & & & & & & & \\
\hline & 0 & 20 & 35 & 0 & 20 & 35 & 0 & 20 & 35 & 0 & 20 & 35 & $\mathrm{P}$ & s & w & $\mathrm{P} \times \mathrm{S}$ & $\mathrm{P} \times \mathrm{W}$ & $\mathrm{s} \times \mathrm{W}$ & $\mathrm{P} \times \mathrm{S} \times \mathrm{W}$ \\
\hline Mesophiles & $8.21^{\mathrm{d}} \pm 0.28$ & $7.51^{\mathrm{c}, \mathrm{d}} \pm 0.18$ & $6.22^{\mathrm{a}, \mathrm{b}} \pm 0.19$ & $7.16^{b, c} \pm 0.11$ & $6.39^{\mathrm{a}, \mathrm{b}} \pm 0.64$ & $7.59^{\mathrm{c}, \mathrm{d}} \pm 0.71$ & $8.21^{\mathrm{d}} \pm 0.28$ & $6.14^{\mathrm{a}} \pm 0.19$ & $8.21^{\mathrm{d}} \pm 0.21$ & $7.16^{b, c} \pm 0.11$ & $6.35^{\mathrm{a}, \mathrm{b}} \pm 0.40$ & $6.42^{2, \mathrm{a} b} \pm 0.12$ & $\mathrm{~ns}$ & *** & **** & * & ** & * & $* * *$ \\
\hline & $5.29 \pm 4.59$ & $7.73 \pm 0.50$ & $7.82 \pm 0.15$ & $6.78 \pm 1.22$ & $7.13 \pm 0.02$ & $8.24 \pm 0.37$ & $5.29 \pm 4.59$ & $7.60 \pm 0.47$ & $9.48 \pm 0.19$ & $6.78 \pm 1.22$ & $8.12 \pm 0.02$ & $6.75 \pm 0.36$ & ns & ns & $*$ & ns & ns & ns & ns \\
\hline Enterobacteria & $6.80^{c} \pm 0.44$ & $3.61^{\mathrm{a}, \mathrm{b}, \mathrm{c}} \pm 0.63$ & $2.03^{\mathrm{a}, \mathrm{b}} \pm 0.58$ & $4.80^{\mathrm{b}, \mathrm{c}} \pm 2.88$ & $4.41^{\mathrm{b}, \mathrm{c}} \pm 0.49$ & $2.71^{\mathrm{a}, \mathrm{b}} \pm 0.14$ & $6.80^{c} \pm 0.44$ & $1.83^{\mathrm{a}, \mathrm{b}} \pm 0.20$ & $1.39^{\mathrm{a}, \mathrm{b}} \pm 1.19$ & $4.80^{\mathrm{b}, \mathrm{c}} \pm 2.88$ & $3.09^{\mathrm{a}, \mathrm{b}, \mathrm{c}} \pm 0.06$ & ND & * & ns & $* * *$ & ns & ns & * & ns \\
\hline Enterococci & $1.59 \pm 1.65$ & $2.83 \pm 0.17$ & $1.73 \pm 0.15$ & $2.77 \pm 3.60$ & $3.96 \pm 0.42$ & $1.27 \pm 0.12$ & $1.59 \pm 1.65$ & $2.37 \pm 0.10$ & $2.74 \pm 0.16$ & $2.77 \pm 3.60$ & $1.63 \pm 0.31$ & $1.68 \pm 0.33$ & ns & ns & ns & ns & ns & ns & ns \\
\hline Staphylococci & $3.74^{a, b} \pm 0.39$ & $2.77^{\mathrm{a}} \pm 0.86$ & $3.26^{a, b} \pm 0.24$ & $3.50^{\mathrm{a}, \mathrm{b}} \pm 0.13$ & $4.57^{\mathrm{b}} \pm 0.05$ & $4.49^{\mathrm{b}} \pm 0.24$ & $3.74^{\mathrm{a}, \mathrm{b}} \pm 0.39$ & $3.36^{\mathrm{a}, \mathrm{b}} \pm 0.32$ & $3.29^{\mathrm{a}, \mathrm{b}} \pm 0.19$ & $3.50^{\mathrm{a}, \mathrm{b}} \pm 0.13$ & $4.18^{8} \pm 1.03$ & $4.04^{\mathrm{a}, \mathrm{b}} \pm 0.27$ & ns & $* * *$ & ns & ns & ns & $* * *$ & ns \\
\hline $\begin{array}{l}\text { Yeasts } \\
\text { Youd }\end{array}$ & $4.89^{\mathrm{a}, \mathrm{b}, \mathrm{c}, \mathrm{c}} \pm 0.14$ & $3.82^{\mathrm{a}, \mathrm{b}, \mathrm{b}, \mathrm{c}} \pm 0.29$ & $3.51^{\mathrm{a}} \pm 0.21$ & $4.53^{\mathrm{a}, \mathrm{b}, \mathrm{c}, \mathrm{c}} \pm 0.16$ & $5.44^{\mathrm{c}} \pm 0.02$ & $4.61^{\mathrm{a}, \mathrm{b}, \mathrm{c},} \pm 1.44$ & $4.89^{\mathrm{a}, \mathrm{b}, \mathrm{c}, \mathrm{c}} \pm 0.14$ & $3.70^{a, b} \pm 0.47$ & $4.44^{\mathrm{a}, \mathrm{b}, \mathrm{c}} \pm 0.75$ & $4.53^{\mathrm{a}, \mathrm{b}, \mathrm{c}, \mathrm{c}} \pm 0.16$ & $5.18^{\mathrm{b}, \mathrm{c}} \pm 0.76$ & $4.93^{\mathrm{a}, \mathrm{b}} \pm 0.25$ & ns & $* *$ & ns & ns & ns & $* *$ & ns \\
\hline
\end{tabular}

Microbial counts are expressed in $\log$ cfu $^{-1}$ (mean \pm SD). Within the same row, different letters represent significantly different arithmetic means (Tukey’s HSD test).

ND-not detected.

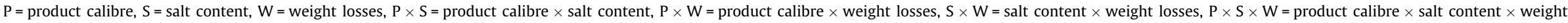
losses.

ns $=$ not significant, ${ }^{*} \mathrm{p}<0.05,{ }^{* *} \mathrm{p}<0.01,{ }^{* * *} \mathrm{p}<0.001$

Factorial ANOVA for biogenic amines levels (fresh matter), detected throughout the ripening process (\% weight losses), concerning product calibre and salt content.

\begin{tabular}{|c|c|c|c|c|c|c|c|c|c|c|c|c|c|c|c|c|c|c|}
\hline \multirow{3}{*}{$\begin{array}{l}\text { Product calibre } \\
\text { Salt content } \\
\text { Weight losses (\%) }\end{array}$} & \multicolumn{6}{|l|}{ “Chouriço Preto" } & \multicolumn{6}{|l|}{ "Paio Preto" } & \multicolumn{6}{|c|}{ Significance } \\
\hline & \multicolumn{3}{|l|}{$3 \% \mathrm{NaCl}$} & \multicolumn{3}{|l|}{$6 \% \mathrm{NaCl}$} & \multicolumn{3}{|l|}{$3 \% \mathrm{NaCl}$} & \multicolumn{3}{|l|}{$6 \% \mathrm{NaCl}$} & & & & & & \\
\hline & 0 & 20 & 35 & 0 & 20 & 35 & 0 & 20 & 35 & 0 & 20 & 35 & $\mathrm{P}$ & $S$ w & $\mathrm{W} P$ & $\times S \mathrm{P} \times W$ & $\mathrm{VS} \times \mathrm{W}$ & $\mathrm{P} \times \mathrm{S} \times \mathrm{W}$ \\
\hline Tryptamine & $19.02^{\mathrm{a}, \mathrm{b}} \pm 2.28$ & $41.22^{b, c, d} \pm 3.35$ & $43.50^{\mathrm{b}, c, \mathrm{~d}} \pm 17.41$ & $47.03^{b, c, d} \pm 23.89$ & $23.11^{\mathrm{a}, \mathrm{b}} \pm 17.11$ & $\mathrm{ND}$ & $19.02^{\mathrm{a}, \mathrm{b}} \pm 2.28$ & $55.29^{\mathrm{c}^{\mathrm{cd}}} \pm 9.63$ & $67.11^{\mathrm{d}} \pm 23.58$ & $47.03^{\mathrm{bccd}} \pm 23.89$ & $32.58^{b, c} \pm 7.57$ & $30.68^{b, c} \pm 2.28$ & $* * * * *$ & ** & & $* *$ & $* * *$ & ns \\
\hline$\beta$-Phenylethylamine & $8.01^{1, c,} \pm 2.45$ & $15.47^{\mathrm{c,d}} \pm 9.82$ & $10.42^{\mathrm{b}, c, \mathrm{c}} \pm 1.59$ & ND & $17.23^{\mathrm{d}} \pm 5.29$ & $38.62^{\mathrm{e}} \pm 4.55$ & $8.01^{b, c} \pm 2.45$ & $6.38^{\mathrm{b}} \pm 0.76$ & $10.45^{\mathrm{b}, c, \mathrm{~d}} \pm 4.46$ & ND & & $12.43^{\mathrm{b}, c, \mathrm{~d}} \pm 1.35$ & $* * * \mathrm{n}$ & & & *** & *** & *** \\
\hline Putrescine & $76.92^{\mathrm{b}} \pm 15.54$ & $173.94^{\mathrm{c}} \pm 4.89$ & $180.11^{\mathrm{c}} \pm 10.95$ & $11.63^{\mathrm{a}} \pm 1.93$ & $258.83^{\mathrm{d}} \pm 4.05$ & $265.36^{\mathrm{d}} \pm 16.03$ & $76.92^{\mathrm{b}} \pm 15.54$ & $159.75^{\mathrm{c}} \pm 4.11$ & $142.31^{c} \pm 68.34$ & $11.63^{\mathrm{a}} \pm 1.93$ & $38.37^{\mathrm{b}} \pm 5.28$ & $81.01^{\mathrm{b}} \pm 24.33$ & $* * * *$ & *** & & *** & *** & *** \\
\hline Cadaverine & $124.54^{\mathrm{c}} \pm 15.60$ & $349.22^{\mathrm{f}} \pm 2.09$ & $364.83^{\mathrm{f}} \pm 20.79$ & ND & ND & ND & $124.54^{\complement} \pm 15.60$ & $169.37^{d} \pm 9.20$ & $270.80^{e} \pm 60.52$ & $\mathrm{ND}$ & $30.46^{\mathrm{a}, \mathrm{b}} \pm 2.86$ & $47.61^{\mathrm{b}} \pm 10.95$ & $* * * * *$ & & & $* * *$ & *** & $* * *$ \\
\hline Histamine & $10.70^{\mathrm{b}} \pm 5.24$ & $12.66^{b, c} \pm 0.94$ & ND & $\mathrm{ND}$ & ND & ND & $10.70^{\mathrm{b}} \pm 5.24$ & $17.47^{c} \pm 2.74$ & $28.87^{\mathrm{d}} \pm 6.35$ & $\mathrm{ND}$ & $9.17^{\mathrm{b}} \pm 4.72$ & ND & $* * * * *$ & & & $* * *$ & ns & *** \\
\hline Tyramine & $75.47^{\mathrm{b}, c} \pm 4.85$ & $150.26^{\mathrm{e}} \pm 2.95$ & $111.02^{\mathrm{c}, \mathrm{d}} \pm 6.96$ & $9.36^{\mathrm{a}} \pm 6.47$ & ND & ND & $75.47^{\mathrm{b}, \mathrm{c}} \pm 4.85$ & $128.73^{\mathrm{de}} \pm 11.14$ & $136.22^{\mathrm{d}, \mathrm{e}} \pm 59.37$ & $9.36^{\mathrm{a}} \pm 6.47$ & $69.51^{\mathrm{b}} \pm 14.98$ & $123.53^{\mathrm{d}, \mathrm{e}} \pm 7.76$ & $* * * *$ & & & $* * *$ & *** & $* * *$ \\
\hline Spermidine & ND & $11.53^{\mathrm{e}} \pm 2.34$ & $9.98^{\mathrm{d}, \mathrm{e}} \pm 4.66$ & ND & ND & $7.24^{\mathrm{c}, \mathrm{d}} \pm 1.58$ & ND & $4.71^{b, c} \pm 0.62$ & $4.01^{\mathrm{b}, \mathrm{c}} \pm 0.37$ & & $2.98^{\mathrm{a}, \mathrm{b}} \pm 1.70$ & $6.48^{c} \pm 1.36$ & $* * * *$ & & & ** & $* * *$ & $* * *$ \\
\hline Spermine & $27.44^{\mathrm{b}} \pm 1.82$ & $40.79^{\mathrm{c}} \pm 2.45$ & $41.03^{\mathrm{c}} \pm 3.30$ & $26.13^{\mathrm{b}} \pm 1.61$ & $\mathrm{ND}$ & $0.31^{\mathrm{a}} \pm 0.00$ & $27.44^{\mathrm{b}} \pm 1.82$ & $34.59^{\mathrm{b}, \mathrm{c}} \pm 13.26$ & $41.21^{\mathrm{c}} \pm 3.45$ & $26.13^{\mathrm{b}} \pm 1.61$ & $34.92^{\mathrm{b}, \bar{c}} \pm 3.43$ & $34.18^{\mathrm{b}, c} \pm 3.39$ & $* * * *$ & & ns $* *$ & $* * *$ & $* * *$ & *** \\
\hline Total amines & $345.40^{\mathrm{d}} \pm 27.45$ & $796.68^{\mathrm{f}} \pm 10.76$ & $752.34^{\mathrm{f}} \pm 42.51$ & $88.86^{\mathrm{a}, \mathrm{b}} \pm 21.48$ & $296.50^{\mathrm{cd} d} \pm 21.02$ & $291.41^{\text {cdd }} \pm 30.58$ & $345.40^{\mathrm{d}} \pm 7.45$ & $585.46^{e} \pm 21.61$ & $644.55^{e} \pm 100.88$ & $88.86^{\mathrm{ab}} \pm 21.48$ & $214.93^{\mathrm{b}, \mathrm{c}} \pm 15.95$ & $332.13^{\mathrm{d}} \pm 15.67$ & $* * * *$ & & $* * * * *$ & $* * *$ & $* * *$ & $* *$ \\
\hline Vasoactive amines & $116.50^{\circ} \pm 9.18$ & $221.21^{\mathrm{e}^{-}} \pm 12.48$ & $159.73^{\mathrm{d}} \pm 20.76$ & $56.38^{\mathrm{b}} \pm 23.28$ & $41.15^{\mathrm{a}, \mathrm{b}} \pm 18.76$ & $19.31^{\mathrm{a}} \pm 21.64$ & $116.50^{\circ} \pm 9.18$ & $210.81^{ \pm} \pm 12.64$ & $292.77^{\mathrm{f}} \pm 24.97$ & $56.38^{\mathrm{b}} \pm 23.28$ & $108.21^{\complement} \pm 14.32$ & $164.15^{\mathrm{d}} \pm 9.57$ & $* * * *$ & $* * * *$ & $* * * *$ & $* * *$ & $* * *$ & $* * *$ \\
\hline
\end{tabular}

Biogenic amines content is expressed in $\mathrm{mg} \mathrm{kg}^{-1}$ of fresh matter (mean $\pm \mathrm{SD}$ ). Within the same row, different letters represent significantly different arithmetic means (Tukey's HSD test).

ND-not detected.

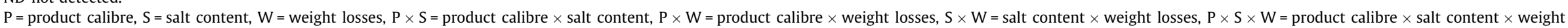
losses.

ns $=$ not significant, ${ }^{*} \mathrm{p}<0.05,{ }^{* *} \mathrm{p}<0.01,{ }^{* * *} \mathrm{p}<0.001$. 
Table 3

Fatty acids (\% of total fatty acids) profile of end-products (35\% weight losses) regarding product calibre and salt content.

\begin{tabular}{|c|c|c|c|c|c|}
\hline & \multirow{2}{*}{$\begin{array}{l}\text { Product calibre } \\
\text { Salt content }\end{array}$} & \multicolumn{2}{|c|}{ "Chouriço Preto" } & \multicolumn{2}{|l|}{ “Paio Preto" } \\
\hline & & $3 \% \mathrm{NaCl}$ & $6 \% \mathrm{NaCl}$ & $3 \% \mathrm{NaCl}$ & $6 \% \mathrm{NaCl}$ \\
\hline \multirow[t]{16}{*}{ Fatty Acids } & Lauric (C12:0) & $0.06 \pm 0.02$ & $0.09 \pm 0.03$ & $0.20 \pm 0.28$ & $0.29 \pm 0.19$ \\
\hline & Myristic (C14:0) & $1.20 \pm 0.16$ & $1.14 \pm 0.15$ & $1.22 \pm 0.08$ & $1.39 \pm 0.10$ \\
\hline & Palmitic (C16:0) & $23.30 \pm 2.96$ & $22.81 \pm 2.88$ & $25.06 \pm 0.44$ & $24.45 \pm 0.78$ \\
\hline & Palmitoleic (C16:1) & $2.47 \pm 0.28$ & $2.40 \pm 0.48$ & $2.58 \pm 0.13$ & $2.00 \pm 1.38$ \\
\hline & Margaric (C17:0) & $0.34 \pm 0.08$ & $0.33 \pm 0.05$ & $0.43 \pm 0.08$ & $0.24 \pm 0.11$ \\
\hline & Margaroleic (C17:1) & $0.37 \pm 0.04$ & $0.30 \pm 0.09$ & $0.40 \pm 0.02$ & $0.34 \pm 0.12$ \\
\hline & Stearic (C18:0) & $12.13 \pm 1.77$ & $12.45 \pm 1.50$ & $13.53 \pm 0.49$ & $12.73 \pm 0.80$ \\
\hline & Oleic (C18:1) & $40.65 \pm 4.70$ & $43.91 \pm 5.81$ & $47.20 \pm 1.28$ & $45.25 \pm 0.83$ \\
\hline & Linoleic (C18:2) & $5.54 \pm 0.70$ & $5.29 \pm 0.47$ & $5.52 \pm 0.51$ & $5.64 \pm 0.48$ \\
\hline & Linolenic (C18:3) & $0.48 \pm 0.05$ & $0.45 \pm 0.02$ & $0.40 \pm 0.07$ & $0.46 \pm 0.11$ \\
\hline & Gadoleic (C20:1) & $1.00 \pm 0.07$ & $0.82 \pm 0.17$ & $1.05 \pm 0.04$ & $0.99 \pm 0.08$ \\
\hline & Heneicosanoic (C21:1) & $0.28 \pm 0.11$ & $0.32 \pm 0.09$ & $0.21 \pm 0.05$ & $0.38 \pm 0.13$ \\
\hline & MUFA & $44.76 \pm 5.17$ & $47.74 \pm 6.51$ & $51.44 \pm 1.35$ & $48.96 \pm 0.47$ \\
\hline & PUFA & $6.02 \pm 0.75$ & $5.74 \pm 0.46$ & $5.92 \pm 0.52$ & $6.10 \pm 0.50$ \\
\hline & SFA & $37.03 \pm 4.90$ & $36.83 \pm 4.57$ & $40.44 \pm 1.36$ & $39.10 \pm 1.27$ \\
\hline & $\mathrm{P} / \mathrm{S}$ ratio & 0.16 & 0.16 & 0.15 & 0.16 \\
\hline
\end{tabular}

Fatty acids content is expressed as $\%$ mean \pm SD.

Table 4

Two-way ANOVA for texture profile analysis parameters of end-products (35\% weight losses), concerning product calibre and salt content.

\begin{tabular}{|c|c|c|c|c|c|c|c|}
\hline \multirow{2}{*}{$\begin{array}{l}\text { Product calibre } \\
\text { Salt content }\end{array}$} & \multicolumn{2}{|c|}{ "Chouriço Preto" } & \multicolumn{2}{|l|}{ "Paio Preto" } & \multicolumn{3}{|c|}{ Significance } \\
\hline & $3 \% \mathrm{NaCl}$ & $6 \% \mathrm{NaCl}$ & $3 \% \mathrm{NaCl}$ & $6 \% \mathrm{NaCl}$ & $\mathrm{P}$ & $\mathrm{S}$ & $\mathrm{P} \times \mathrm{S}$ \\
\hline Hardness $(\mathrm{N})$ & $44.49^{\mathrm{a}} \pm 8.08$ & $43.49^{\mathrm{a}} \pm 7.83$ & $52.26^{\mathrm{a}, \mathrm{b}} \pm 23.61$ & $61.41^{\mathrm{b}} \pm 11.50$ & $* * *$ & ns & ns \\
\hline Adhesiveness $(\mathrm{N} \times \mathrm{s})$ & $-1.89 \pm 0.89$ & $-2.86 \pm 1.23$ & $-3.17 \pm 2.69$ & $-2.52 \pm 0.88$ & ns & ns & ns \\
\hline Cohesiveness & $0.49^{\mathrm{b}} \pm 0.05$ & $0.55^{c} \pm 0.04$ & $0.39^{a} \pm 0.03$ & $0.57^{c} \pm 0.04$ & $* * *$ & $* * *$ & $* * *$ \\
\hline Springiness (mm) & $0.97 \pm 0.29$ & $0.94 \pm 0.10$ & $0.90 \pm 0.08$ & $1.03 \pm 0.32$ & ns & ns & ns \\
\hline Resilience & $0.14^{\mathrm{b}} \pm 0.02$ & $0.17^{c} \pm 0.01$ & $0.09^{\mathrm{a}} \pm 0.02$ & $0.20^{\mathrm{d}} \pm 0.03$ & $* *$ & $* * *$ & $* * *$ \\
\hline Chewiness $(\mathrm{N} \times \mathrm{mm})$ & $20.86^{\mathrm{a}} \pm 4.74$ & $22.12^{\mathrm{a}} \pm 3.51$ & $18.22^{\mathrm{a}} \pm 8.87$ & $35.69^{\mathrm{b}} \pm 11.17$ & $* *$ & $* * *$ & $* * *$ \\
\hline
\end{tabular}

Data are expressed as means \pm SD. Within the same row, different letters represent significantly different arithmetic means (Tukey's HSD test).

$\mathrm{P}=$ product calibre, $\mathrm{S}=$ salt content, $\mathrm{P} \times \mathrm{S}=$ product calibre $\times$ salt content.

ns = not significant, ${ }^{* *} \mathrm{p}<0.01,{ }^{* * *} \mathrm{p}<0.001$.

$200 \mathrm{mg} \mathrm{kg}^{-1}$ fresh matter (Eerola et al., 1998). In the present study, vasoactive amines ranged from 19.31 up to $292.77 \mathrm{mg} \mathrm{kg}^{-1}$ (Table 2). Due to the high levels of tyramine and tryptamine, vasoactive amines occasionally surpassed the recommended upper limit in low-salt sausages. However, among end-products, low-salt PP (292.77 $\left.\mathrm{mg} \mathrm{kg}^{-1}\right)$ was the only product for which the sum of vasoactive amines exceeded the recommended limits.

Although low-salt products showed higher histamine levels (nil to $28.87 \mathrm{mg} \mathrm{kg}^{-1}$ fresh matter) (Table 2), they generally remained below the $100 \mathrm{mg} \mathrm{kg}^{-1}$ fresh matter acceptable limit (Stadnik \& Dolatowski, 2010).

Regarding food safety, histamine and tyramine are the major causes for food poisoning by biogenic amines (Mah \& Hwang, 2009).

$\mathrm{NaCl}$ has been widely used by meat industry as a way to inhibit the undesired growth of microorganisms with decarboxylase activity and, concomitantly, minimising the formation of biogenic amines (Suzzi \& Gardini, 2003). Reducing salt leads to higher levels of biogenic amines, not only during early processing stages, but also in end-products. Furthermore, the decarboxylation of lysine, ornithine and tyrosine, the amino acid precursors of the most abundant amines, cadaverine, putrescine and tyramine, respectively, is promoted by bacterial enzymes of food microorganisms, such as enterobacteria and LAB (Suzzi \& Gardini, 2003). Despite the absence of statistical differences between enterobacteria initial counts in low- and regular-salt sausages, less enterobacteria in the regular-salt meat batter correspond to an absence of cadaverine, and to significant lower levels of putrescine, when compared to low-salt products. Enterobacteria decline throughout ripening, due to the decrease of $\mathrm{pH}$ and $\mathrm{a}_{\mathrm{w}}$, however decarboxylases remain active and contribute to the accumulation of biogenic amines. A possible explanation for the discrepancy found between cadaverine and putrescine levels may be a combination of multiple factors concerning the existing microbiota. Although the formation of cadaverine and putrescine is primarily associated with decarboxylation of lysine and ornithine, respectively, by enterobacteria, it is known that decarboxylase activity may also be found in other bacteria, such as enterococci and staphylococci (Martín et al., 2006). Moreover, the ability to decarboxylate amino acids is more strain- rather than species-dependent (Durlu-Özkaya, Ayhan, \& Vural, 2001).

Tyramine appears mainly as result of LAB activity, which are the main microorganisms involved in the fermentation process. The close relationship between tyramine and fermentation in drycured sausages has led to its often identification as the most abundant amine (De Mey et al., 2014). This is not the case in our study, despite the higher tyramine concentrations found in products with higher LAB counts, which is in good agreement with other works regarding Portuguese traditional dry-cured sausages (LatorreMoratalla et al., 2008; Roseiro et al., 2010).

Concerning tryptamine and $\beta$-phenylethylamine, both biogenic amines of bacterial origin, usually low levels are reported (Papavergou, Savvaidis, \& Ambrosiadis, 2012), which was confirmed in our study. Despite the changes in the concentrations of these two biogenic amines throughout ripening, opposite evolution patterns could be observed in products containing $6 \%$ salt. For these sausages, the highest levels of tryptamine were detected in meat batters and were progressively reduced, since tryptamine 
can be used as a nitrogen source by microorganisms (Gardini, Martuscelli, Crudele, Paparella, \& Suzzi, 2002). On the contrary, $\beta$-phenylethylamine was not detected in meat batters and the highest concentrations were found in end-products.

Biogenic amines contamination levels of dry-cured sausages are highly dependent on process technologies. Indeed, quite distinct results have been reported for Portuguese traditional dry-cured sausages, however the results obtained in the present study are similar to others previously reported (Latorre-Moratalla et al., 2008; Roseiro et al., 2006; Roseiro et al., 2008; Roseiro et al., 2010).

\subsection{Fatty acids profile}

The profile of fatty acids is summarised in Table 3.

No significant differences were observed due to both product calibre $(P>0.05)$ and salt content $(P>0.05)$. Monounsaturated fatty acids (MUFA) are the most abundant, largely due to the oleic acid fraction, which ranged from $40.65 \%$ to $47.20 \%$. MUFA were followed by saturated fatty acids (SFA) with palmitic acid accounting to $22.81-25.06 \%$ and stearic acid from $12.13 \%$ to $13.53 \%$. Linoleic acid (5.29-5.64\%) was the most relevant polyunsaturated fatty acid (PUFA).

This fatty acid profile is consistent with the typical profile usually found in Alentejano pig breed fat (Teixeira \& Rodrigues, 2013) that was used for manufacturing both $\mathrm{CP}$ and PP sausages, as well as with the results reported by Elias and Carrascosa (2010). Since SFA composition is related to several health issues, like cardiovascular diseases and cholesterolemia among others, it is important to keep an adequate proportion of PUFA and SFA. According to Wood et al. (2003), a PUFA/SFA (P/S) ratio higher than 0.4 is recommended. In our study $\mathrm{P} / \mathrm{S}$ ratios were below this reference value, ranging from 0.15 to 0.16 (Table 3 ). This is due to low content in PUFA, which might be explained by the involvement of spermine and spermidine in oxidative reactions, with the subsequent probable inhibition of PUFA as described before (Martuscelli et al., 2009). Consequently, higher PUFA contents are desirable in order to obtain healthier products.

\subsection{Texture profile analysis (TPA)}

Table 4 shows the most relevant textural parameters evaluated in the TPA test.

Important changes on products' texture were observed due to product calibre (hardness, cohesiveness, resilience and chewiness) and salt reduction (cohesiveness, resilience and chewiness). Both
$\mathrm{CP}$ and PP showed lower cohesiveness and resilience levels in low-salt $(3 \%)$ products $(P<0.05)$ (Table 4$)$. This difference is more evident in large calibre products, as pointed out by the significant interaction between product calibre and salt content for cohesiveness, resilience and chewiness $(P<0.001)$. A similar trend was observed for hardness and chewiness in PP samples. Therefore, product calibre and salt content both have decisive roles on the textural development of this type of dry-cured sausages. Similar studies agree with our results, highlighting the positive effect of salt in sausages' texture (Benedini, Parolari, Toscani, \& Virgili, 2012).

\subsection{Sensory evaluation}

The sensory attributes evaluated by the trained panel are shown in Table 5.

No differences were observed between product calibres and salt contents for most of the analysed attributes. However, the attributes "off flavours" $(P<0.01)$ and "overall appreciation" $(P<0.05)$ showed significant differences between sausages with different calibres. Regarding salt content, differences were detected for "off-flavours", "salt perception" and "overall appreciation" $(P<0.01)$.

A clear preference for low-salt dry-cured sausages was observed, as highlighted by the higher rates assigned (74/100 and 73/100 for CP and PP, respectively, for the "overall appreciation" attribute). On the contrary, in regular-salt sausages, salt was clearly identified by the panellists ("salt perception" rated with $66 / 100$ and $63 / 100$ for CP and PP, respectively) and a salty taste was often reported (data not shown), with a negative impact on the products' "overall appreciation".

Regardless of product type, rates attributed by the panellists revealed a quite positive appreciation, regarding colour, aroma and flavour. The presence of negative flavours was seldom reported, except for one evaluation session, where panellists denoted a rancidity taste, in 6\% PP. This justifies the detected interaction between product calibre and salt content $(P<0.01)$. Panellists taking part in our study were trained and highly experienced and so rates between triplicates were quite consistent, which confers a high reliability to these results (data not shown). Nonetheless, in this specific replicate, the rancid flavour reported by most panellists could be due to effect of salt in potentiating lipid oxidation (Desmond, 2006).

A PCA was run taking into account the textural parameters from both TPA and sensory evaluation (data not shown). From the

Table 5

Two-way ANOVA for sensory evaluation attributes of end-products (35\% weight losses) regarding product calibre and salt content.

\begin{tabular}{|c|c|c|c|c|c|c|c|}
\hline \multirow{2}{*}{$\begin{array}{l}\text { Product calibre } \\
\text { Salt content }\end{array}$} & \multicolumn{2}{|c|}{ "Chouriço Preto" } & \multicolumn{2}{|c|}{ "Paio Preto" } & \multicolumn{3}{|c|}{ Significance } \\
\hline & $3 \% \mathrm{NaCl}$ & $6 \% \mathrm{NaCl}$ & $3 \% \mathrm{NaCl}$ & $6 \% \mathrm{NaCl}$ & $\mathrm{P}$ & $\mathrm{S}$ & $\mathrm{P} \times \mathrm{S}$ \\
\hline Colour intensity & $75 \pm 15$ & $77 \pm 12$ & $72 \pm 14$ & $76 \pm 15$ & ns & ns & ns \\
\hline Off-colours & ND & ND & ND & ND & ns & ns & ns \\
\hline Marbled & $68 \pm 20$ & $62 \pm 21$ & $59 \pm 20$ & $59 \pm 23$ & ns & ns & ns \\
\hline Aroma intensity & $75 \pm 10$ & $72 \pm 12$ & $72 \pm 15$ & $67 \pm 15$ & ns & ns & ns \\
\hline Off-aromas & ND & $3 \pm 15$ & ND & $3 \pm 6$ & ns & ns & ns \\
\hline Hardness & $57 \pm 13$ & $54 \pm 8$ & $58 \pm 10$ & $55 \pm 7$ & ns & ns & ns \\
\hline Fibrousness & $27 \pm 34$ & $29 \pm 28$ & $31 \pm 23$ & $20 \pm 22$ & ns & ns & ns \\
\hline Succulence & $69 \pm 13$ & $68 \pm 10$ & $65 \pm 14$ & $64 \pm 11$ & ns & ns & ns \\
\hline Flavour intensity & $74 \pm 12$ & $74 \pm 10$ & $72 \pm 9$ & $70 \pm 12$ & ns & ns & ns \\
\hline Off-flavours & $0^{\mathrm{a}} \pm 1$ & $0^{\mathrm{a}} \pm 2$ & $0^{\mathrm{a}} \pm 2$ & $5^{b} \pm 7$ & $* *$ & $*$ & $* *$ \\
\hline Salt perception & $59^{\mathrm{a}, \mathrm{b}} \pm 11$ & $66^{\mathrm{b}} \pm 10$ & $55^{\mathrm{a}} \pm 8$ & $63^{\mathrm{a}, \mathrm{b}} \pm 12$ & ns & $* *$ & ns \\
\hline Overall appreciation & $74^{\mathrm{b}} \pm 15$ & $69^{\mathrm{a}, \mathrm{b}} \pm 12$ & $73^{\mathrm{b}} \pm 12$ & $60^{\mathrm{a}} \pm 14$ & $*$ & $* *$ & ns \\
\hline
\end{tabular}

Data are expressed as mean \pm SD. Within the same row, different letters represent significantly different arithmetic means (Tukey's HSD test).

ND-not detected.

$\mathrm{P}=$ product calibre, $\mathrm{S}=$ salt content, $\mathrm{P} \times \mathrm{S}=$ product calibre $\times$ salt content.

ns = not significant, ${ }^{*} \mathrm{p}<0.05,{ }^{* *} \mathrm{p}<0.01$ 
loading factors three components were extracted, whereas the two main factors explained $83.48 \%$ of the observed variance (data not shown). The major proportion of variance was explained by PC1 (53.73\%), where the most important variables are sensory fibrousness and textural cohesiveness, springiness and resilience (data not shown). Despite no differences were perceived from the sensory evaluation regarding the samples' texture (Table 5), the PCA revealed higher cohesiveness and resilience values in regular-salt sausages (CP6 and PP6), resulting from the better binding between meat portions favoured by salt. Sensory succulence and textural adhesiveness were the two variables that contribute the most to PC2 (data not shown). Moreover, a positive correlation was observed between succulence rated by the panellists and adhesiveness measurements, which was also reported by Elias et al. (2014).

\subsection{Conclusions}

Salt reduction had a positive effect on products' acceptance by the panellists without compromising microbiological stability or fatty acids profile of dry-cured sausages. However, biogenic amines levels increased, which may represent a health risk, particularly for susceptible consumers. Therefore, and taking the safety of these traditional meat products into account, the results obtained for $\mathrm{pH}, \mathrm{a}_{\mathrm{w}}$ and biogenic amines contents, have shown that reducing salt should be complemented with the use of starter cultures to minimise the levels of biogenic amines, as an additional safety measure.

Furthermore, the results obtained in our study may also be applied to other traditional dry-cured sausages, manufactured by similar production processes, in Portugal or in other countries.

\section{Acknowledgments}

This work was funded by national funds by project PRODER 13.021 (QREN/PRODER/Medida 4.1) and also through Fundação para a Ciência e a Tecnologia (FCT) under the Project UID/ AGR/00115/2013. M. Laranjo acknowledges a Post-Doc research grant from FCT (SFRH/BPD/108802/2015). The authors wish to thank PALADARES ALENTEJANOS, Lda. for their collaboration and A. Oliveira and G. Pias for their technical assistance.

\section{References}

Ambrosiadis, J., Soultos, N., Abrahim, A., \& Bloukas, J. G. (2004). Physicochemical, microbiological and sensory attributes for the characterization of Greek traditional sausages. Meat Science, 66, 279-287.

Benedini, R., Parolari, G., Toscani, T., \& Virgili, R. (2012). Sensory and texture properties of Italian typical dry-cured hams as related to maturation time and salt content. Meat Science, 90, 431-437.

Bibbins-Domingo, K., Chertow, G. M., Coxson, P. G., Moran, A., Lightwood, J. M., Pletcher, M. J., \& Goldman, L. (2010). Projected effect of dietary salt reductions on future cardiovascular disease. New England Journal of Medicine, 362, 590-599.

Bover-Cid, S., Schoppen, S., Izquierdo-Pulido, M., \& Vidal-Carou, M. C. (1999). Relationship between biogenic amine contents and the size of dry fermented sausages. Meat Science, 51, 305-311.

Corral, S., Salvador, A., \& Flores, M. (2013). Salt reduction in slow fermented sausages affects the generation of aroma active compounds. Meat Science, 93(3), 776-785.

De Mey, E., De Klerck, K., De Maere, H., Dewulf, L., Derdelinckx, G., Peeters, M.-C., Fraeye, I., et al. (2014). The occurrence of N-nitrosamines, residual nitrite and biogenic amines in commercial dry fermented sausages and evaluation of their occasional relation. Meat Science, 96, 821-828.

Desmond, E. (2006). Reducing salt: A challenge for the meat industry. Meat Science, $74,188-196$.

Durlu-Özkaya, F., Ayhan, K., \& Vural, N. (2001). Biogenic amines produced by Enterobacteriaceae isolated from meat products. Meat Science, 58(2), 163-166.

Eerola, H. S., Sagues, A. X. R., \& Hirvi, T. K. (1998). Biogenic amines in Finnish dry sausages. Journal of Food Safety, 18(2), 127-138.

Elias, M., \& Carrascosa, A. V. (2010). Characterisation of the Paio do Alentejo, a traditional Portuguese Iberian sausage, in respect to its safety. Food Control, 21, 97-102.

Elias, M., Potes, M. E., Roseiro, L. C., Santos, C., Gomes, A., \& Agulheiro-Santos, A. C. (2014). The effect of starter cultures on the Portuguese traditional sausage "Paio do Alentejo" in terms of its sensory and textural characteristics and polycyclic aromatic hydrocarbons profile. Journal of Food Research, 3, 45-56.

Gardini, F., Martuscelli, M., Crudele, M. A., Paparella, A., \& Suzzi, G. (2002). Use of Staphylococcus xylosus as a starter culture in dried sausages: Effect on the biogenic amine content. Meat Science, 61(3), 275-283.

Guardia, M. D., Guerrero, L., Gelabert, J., Gou, P., \& Arnau, J. (2006). Consumer attitude towards sodium reduction in meat products and acceptability of fermented sausages with reduced sodium content. Meat Science, 73, 484-490.

ISO (1993). Sensory analysis-General guidance for the selection, training and monitoring of assessors-Part 1: Selected assessors. In, vol. ISO 8586-1.

ISO (1996). Meat and meat products - Determination of chloride content - Part 1: Volhard method. In, vol. ISO 1841-1.

ISO (1999). Meat and meat products - Measurement of pH (Reference method). In, vol. ISO 2917.

ISO (2002). Microbiology of food and animal feeding stuffs-Horizontal method for the detection of Salmonella spp. In, vol. ISO 6579

ISO (2006). Microbiology of food and animal feeding stuffs - Horizontal method for detection and enumeration of Campylobacter spp. In, vol. ISO 10272-2.

ISO (2012a). Microbiology of food and animal feeding stuffs - Horizontal method for the enumeration of beta-glucuronidase-positive Escherichia coli - Part 2 : Colony-count technique at 44 degrees $C$ using 5-bromo-4-chloro-3-indolyl beta-D-glucuronide. In, vol. ISO 16649-2.

ISO (2012b). Sensory analysis-General guidance for the design of test rooms. In, vol. ISO 8589.

ISO (2014). Microbiology of the food chain - Horizontal method for the detection and enumeration of Listeria monocytogenes and of Listeria spp. - Part 2: Enumeration method. In, vol. ISO 11290-2.

Laranjo, M., Agulheiro-Santos, A. C., Potes, M. E., Cabrita, M. J., Garcia, R., Fraqueza, M. J., \& Elias, M. (2015). Effects of genotype, salt content and calibre on quality of traditional dry-fermented sausages. Food Control, 56, 119-127.

Laranjo, M., Gomes, A., Agulheiro-Santos, A. C., Potes, M. E., Cabrita, M. J., Garcia, R. Rocha, J. M., et al. (2016). Characterisation of "Catalão" and "Salsichão" Portuguese traditional sausages with salt reduction. Meat Science, 116, 34-42.

Latorre-Moratalla, M. L., Veciana-Nogués, T., Bover-Cid, S., Garriga, M., Aymerich, T., Zanardi, E., Ianieri, A., et al. (2008). Biogenic amines in traditional fermented sausages produced in selected European countries. Food Chemistry, 107(2), 912-921.

Mah, J.-H., \& Hwang, H.-J. (2009). Effects of food additives on biogenic amine formation in Myeolchi-jeot, a salted and fermented anchovy (Engraulis japonicus). Food Chemistry, 114(1), 168-173.

Martín, B., Garriga, M., Hugas, M., Bover-Cid, S., Veciana-Nogués, M. T., \& Aymerich, T. (2006). Molecular, technological and safety characterization of Gram-positive catalase-positive cocci from slightly fermented sausages. International Journal of Food Microbiology, 107(2), 148-158.

Martuscelli, M., Pittia, P., Casamassima, L. M., Manetta, A. C., Lupieri, L., \& Neri, L. (2009). Effect of intensity of smoking treatment on the free amino acids and biogenic amines occurrence in dry cured ham. Food Chemistry, 116(4), 955-962.

Moretti, V. M., Madonia, G., Diaferia, C., Mentasti, T., Paleari, M. A., Panseri, S., Pirone, G., et al. (2004). Chemical and microbiological parameters and sensory attributes of a typical Sicilian salami ripened in different conditions. Meat Science, 66(4), 845-854.

Olivares, A., Navarro, J. L., Salvador, A., \& Flores, M. (2010). Sensory acceptability of slow fermented sausages based on fat content and ripening time. Meat Science, 86(2), 251-257.

Papavergou, E. J., Savvaidis, I. N., \& Ambrosiadis, I. A. (2012). Levels of biogenic amines in retail market fermented meat products. Food Chemistry, 135(4), 2750-2755.

Parés, D., Saguer, E., \& Carretero, C. (2011). Blood by-products as ingredients in processed meat. In J. P. Kerry \& J. F. Kerry (Eds.), Processed meats: Improving safety, nutrition and quality (pp. 218-242). Cambridge: Woodhead Publishing Limited.

Roseiro, L. C., Gomes, A., Gonçalves, H., Sol, M., Cercas, R., \& Santos, C. (2010). Effect of processing on proteolysis and biogenic amines formation in a Portuguese traditional dry-fermented ripened sausage "Chouriço Grosso de Estremoz e Borba PGI". Meat Science, 84(1), 172-179.

Roseiro, L. C., Santos, C., Sol, M., Borges, M. J., Anjos, M., Gonçalves, H., \& Carvalho, A S. (2008). Proteolysis in Painho de Portalegre dry fermented sausage in relation to ripening time and salt content. Meat Science, 79(4), 784-794.

Roseiro, C., Santos, C., Sol, M., Silva, L., \& Fernandes, I. (2006). Prevalence of biogenic amines during ripening of a traditional dry fermented pork sausage and its relation to the amount of sodium chloride added. Meat Science, 74, 557-563.

Ruusunen, M., \& Puolanne, E. (2005). Reducing sodium intake from meat products. Meat Science, 70, 531-541.

Stadnik, J., \& Dolatowski, Z. J. (2010). Biogenic amines in meat and fermented meat products. ACTA Scientiarum Polonorum Technologia Alimentaria, 9, 251-263.

Suzzi, G., \& Gardini, F. (2003). Biogenic amines in dry fermented sausages: A review. International Journal of Food Microbiology, 88, 41-54.

Teixeira, A., \& Rodrigues, S. (2013). Pork meat quality of Preto Alentejano and commercial largewhite landrace cross. Journal of Integrative Agriculture, 12, 1961-1971.

Wood, J. D., Richardson, R. I., Nute, G. R., Fisher, A. V., Campo, M. M., Kasapidou, E., Sheard, P. R., et al. (2003). Effects of fatty acids on meat quality: A review. Meat Science, 66, 21-32.

Zanardi, E., Ghidini, S., Conter, M., \& Ianieri, A. (2010). Mineral composition of Italian salami and effect of $\mathrm{NaCl}$ partial replacement on compositional, physicochemical and sensory parameters. Meat Science, 86, 742-747. 